(2) norden 



\section{Exposure based waiving and triggering of tests within REACH}

A discussion paper within the Nordic projects on Information Strategies (NOIS)

Agneta Falk-Filipsson and Maria Wallén

TemaNord 2007:562 
Exposure based waiving and triggering of tests within REACH

A discussion paper within the Nordic projects on Information Strategies (NOIS)

TemaNord 2007:562

(C) Nordic Council of Ministers, Copenhagen 2007

ISBN 978-92-893-1543-2

Print:

Cover:

Layout:

Cover photo:

Copies: 0

Printed on environmentally friendly paper

This publication can be ordered on www.norden.org/order. Other Nordic publications are available at www.norden.org/publications

Printed in Denmark

\section{Nordic Council of Ministers}

Store Strandstræde 18

DK-1255 Copenhagen K

Phone (+45) 33960200

Fax (+45) 33960202

\section{Nordic Council}

Store Strandstræde 18

DK-1255 Copenhagen K

Phone (+45) 33960400

Fax (+45) 33111870

www.norden.org

\section{Nordic co-operation}

Nordic cooperation is one of the world's most extensive forms of regional collaboration, involving Denmark, Finland, Iceland, Norway, Sweden, and three autonomous areas: the Faroe Islands, Greenland, and Åland.

Nordic cooperation has firm traditions in politics, the economy, and culture. It plays an important rol in European and international collaboration, and aims at creating a strong Nordic community in a strong Europe.

Nordic cooperation seeks to safeguard Nordic and regional interests and principles in the global community. Common Nordic values help the region solidify its position as one of the world's most innovative and competitive. 


\section{Table of Content}

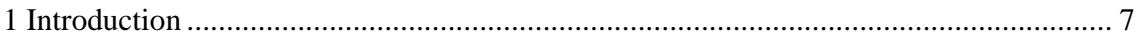

2 Specific rules for adaptation (column 2) of standard information requirements.............. 9

2.1 Toxicological standard information requirements ................................................... 9

2.1.1 Exposure based waiving of toxicological studies ................................... 9

2.1.2 Exposure based triggering of toxicological studies ............................... 13

2.2 Ecotoxicological standard information requirements .......................................... 14

2.2.1 Term in column 2: "Direct and indirect exposure is unlikely" "................ 14

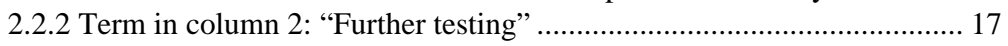

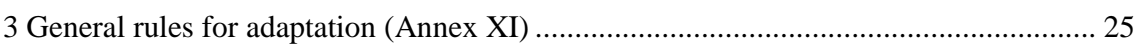

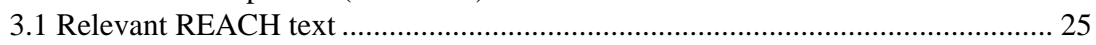

3.1.1 Exposure assessment in the chemical safety assessment ........................ 25

3.1.2 Exposure scenario ................................................................................. 26

3.1.3 General rules for adaptation ............................................................. 27

3.1.4 Relationship between Specific rules for adaptation (Column 2) and the

General rules for adaptation (Annex XI)............................................. 28

4 Possible justification of exposure based waiving........................................................... 31

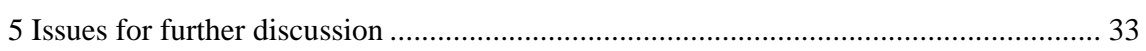

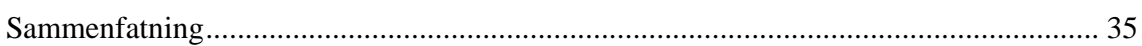





\section{Introduction}

This paper is intended to be a thought-starter and contains attempt to interpret the criteria for adaptation of testing in REACH based on exposure information. It has been prepared under the cover of the Nordic Chemicals Group of the Nordic Council of Ministers. The work was prepared by a consultant within the Nordic projects on Information Strategies (NOIS) and has been guided by a Nordic Steering Group. The document does not necessarily reflect the formal position of the governments of the Nordic countries.

According to REACH, exposure scenario(s) developed in the chemical safety assessment shall demonstrate adequate control. Based on this a decision can be taken whether it is possible to waive tests, or if further testing should be proposed, on a specific tonnage level.

Waiving is in this context defined as omission from the standard information requirement at the actual tonnage level, while triggering is defined as further tests beyond the standard information requirement at the actual tonnage level.

In addition to waiving and triggering, toxicological testing may be adapted by selection of appropriate exposure route based on relevant human exposure. However, this will not be discussed further in this document.

- The main objective of this paper is to give interpretations of the terminology used in Column 2 of Annexes VIII-X for specific exposure based waiving of testing.

- In addition, interpretations are made of the cases where it is proposed in column 2 of Annexes VIII-X that exposure based triggering of testing should be considered.

- Finally, interpretation of the general rules for adaptation in Annex XI are discussed. 



\section{Specific rules for adaptation (column 2) of standard informa- tion requirements}

In the so called "specific rules for adaptation" in column 2 of Annexes VIII, IX and it is specified when and how testing may be adapted for specific endpoints. Some of these rules include exposure considerations.

Our general interpretation of REACH is that waiving is risk-based since it is exposure in relation to an endpoint, or the exposure scenarios developed in the chemical safety assessment, that has to be considered. Thus, it is important that the prerequisites for waiving in column 2 at a specific tonnage level should be considered jointly in its context.

One problem with risk-based waiving that has to be solved is that the study under consideration would in itself be needed in the risk assessment in order to decide if exposure is of no concern in relation to a specific endpoint.

A similar problem arises for human health endpoints in relation to repeated exposure. For instance according to REACH the repeated dose toxicity and/or reproductive toxicity tests in Annex VIII, can be waived even though no toxicity data from repeated exposure is available.

For other endpoints (especially for environmental effects from long-term exposure) the problem might not be equally obvious since data from short-term exposure or physical chemical properties might be used for extrapolation when shown to be protective.

\subsection{Toxicological standard information requirements}

\subsubsection{Exposure based waiving of toxicological studies}

\subsubsection{Term in column 2: "Relevant human exposure"}

According to REACH the short-term repeated dose toxicity study (28days) and the reproductive toxicity study (screening for reproductive/developmental toxicity (OECD 421) or combined repeated dose toxicity study with the reproduction/developmental toxicity screening test (OECD 422)) are required in Annex VIII, 8.6.1 and 8.7.1, respectively.

However, according to column 2 the studies do not need to be conducted if:

"relevant human exposure can be excluded in accordance with Annex XI section 3" 


\section{Interpretations}

The term "relevant" in connection to human exposure is not considered to imply a level/degree of exposure. Instead, it relates to whether the population comes into contact with the substance or not based on initial considerations of how the substance is used. Thus, in general when human exposure to a substance can be expected, waiving is not a possibility.

Especially, when a substance is used in consumer products and/or human exposure may be expected via the environment then relevant human exposure seems difficult to exclude. However, there may be specific cases where the general rules can be deviated e.g. in case it can be proven that a substance is totally chemically reacted during manufacturing or if the substance is permanently bound to a matrix.

Waiving might be considered for occupational exposure on a case-by-case basis, for example when a substance is handled in a closed system.

At this level studies on repeated dose toxicity and reproductive toxicity are requested for the first time.

\subsubsection{Term in column 2: "Limited human exposure"}

According to REACH the sub-chronic toxicity study (90-days) is required in Annex IX, section 8.6.2.

However, according to column 2 the study does not need to be conducted if:

"the substance is unreactive, insoluble, and not inhalable and there is no evidence of absorption and no evidence of toxicity in a 28-days "limit test", particularly if such a pattern is coupled with limited human exposure.”

At this level a short-term repeated dose toxicity study (28-days) should be available as a minimum, unless it is technically impossible to perform the study, or if testing does not appear scientifically necessary (for instance corresponding information can be obtained from other data). 


\section{Interpretations}

Our interpretation of "unreactive" is that it relates to the inherent chemical reactivity in biological systems and as such, is an indicator of lack of local effects and mutagenicity.

“...insoluble and not inhalable” are interpreted as indicators of low exposure potential and should be further defined.

The interpretation of "no evidence of absorption" is that there has to be evidence for lack of absorption from the 28-days "limit test" or other relevant available data in order to omit the study.

Our interpretation of "no evidence of toxicity in a 28-days limit test" is that it has to be at least a 28-days limit test available and this study should not show any sign of toxicity at $1000 \mathrm{mg} / \mathrm{kg}$.

In order to omit the study the prerequisites interpreted above has to be considered jointly since the word "and" is used in between them. In addition, limited human exposure would strengthen the possibility for waiving.

Limited exposure could be considered as exposure below a defined level of exposure, a frequency and/or duration of exposure. In general when repeated human exposure to a substance can be expected, waiving is not a possibility.

Waiving might be considered for occupational exposure on a case-by-case basis, for example when a substance is handled in a closed system or if a very small, well-defined and trained group of people is exposed occasionally to low levels and using appropriate risk management measures.

When a substance is used in consumer products and/or human exposure may be expected via the environment then limited human exposure seems unlikely. However there may be specific cases where the general rules can be deviated, e.g. in case it can be proven that a substance is totally chemically reacted during manufacturing or if the substance is permanently bound to a matrix.

\subsubsection{Term in column 2: "No or no significant exposure"}

According to REACH the pre-natal developmental toxicity study (in accordance with OECD TG 414) and the two-generation reproductive toxicity study are required in sections 8.7.2 and 8.7.3 in Annexes IX and X. However, according to column 2 the studies do not need to be conducted if:

\footnotetext{
" the substance is of low toxicological activity (no evidence of toxicity seen in any of the tests available), it can be proven from toxicokinetic data that no systemic absorption occurs via relevant routes of exposure (e.g. plasma/blood concentrations below detection limit using a sensitive method and absence of substance and of metabolites of the substance in urine, bile or exhaled air), and there is no or no significant human exposure”
} 
At this level a short-term repeated dose toxicity study (28-days) should be available as a minimum, unless it is technically impossible to perform the study, or if testing does not appear scientifically necessary (e.g. corresponding information can be obtained from other techniques based on a weight of evidence approach). In addition, the reproductive toxicity (screening for reproductive/developmental toxicity (OECD 421) or combined repeated dose toxicity study with the reproduction/developmental toxicity screening test (OECD 422)) should be available.

\section{Interpretations}

The interpretation of "no evidence of toxicity" is that no adverse effect has been observed in the available tests.

Our interpretation of "any of the tests available" is that it concerns information from all available data, and as a minimum the tests on the specific tonnage level. It should include toxicological as well as eco-toxicological (e.g. indicating estrogenic effects), testing and non-testing data (e.g. QSAR, relevant analogues, chemical categories and hormone-receptor binding) that can be used in concluding that there is no evidence of toxicity.

To "prove" that no systemic absorption occurs in order to waive a study will in general require convincing evidence from well performed and relevant toxicokinetic studies.

"relevant route” is the route(s) by which humans are expected to be exposed.

"no significant exposure" is defined as a very low level of exposure over a whole lifetime, or a single exposure at a specific occasion. Both the concentration and time is relevant for the determination of no significant exposure.

In general when repeated human exposure to a substance can be expected, waiving is not a possibility.

Waiving might be considered for occupational exposure on a case-by-case basis, for example when a substance is handled in a closed system or if a very small, well-defined and trained group of people is exposed occasionally to low levels and using appropriate risk management measures.

Especially, when a substance is used in consumer products and/or human exposure may be expected via the environment then non-significant human exposure seems unlikely. However there may be specific cases where the general rules can be deviated, e.g. in case it can be proven that a substance is totally chemically reacted during manufacturing or if the substance is permanently bound to a matrix.

In order to omit a study the criteria interpreted above has to be considered jointly in its context since the word "and" is used between them. 


\subsubsection{Exposure based triggering of toxicological studies}

\subsubsection{Term in column 2: "Route of exposure"}

Further studies shall be proposed if:

"The route of exposure in the initial repeated dose study was inappropriate in relation to the expected route of human exposure and route-to-route extrapolation cannot be done.” (REACH Annex VIII, section 8.6.1)

\section{Interpretations}

The oral route is the preferred route for repeated dose testing. However, depending on the physical chemical properties of a substance as well as on the most important route of human exposure the dermal and inhalation route could also be appropriate as specified in REACH, Annexes VIII and IX. For further interpretations see the section "Selection of appropriate exposure route to human” below.

\subsubsection{Term in column 2: "Particular concern regarding exposure"}

\section{Further studies shall be proposed if:}

"Particular concern regarding exposure e.g. use in consumer products leading to exposure levels which are close to the dose levels at which toxicity to humans may be expected.” (REACH Annex VIII, section 8.6.1)

"Particular concern regarding exposure e.g. use in consumer products leading to exposure levels which are high relative to the dose levels at which toxicity to humans may be expected.” (REACH Annex IX, section 8.6.2)

"Particular concern regarding exposure e.g. use in consumer products leading to exposure levels which are close to the dose levels at which toxicity is observed.” (REACH Annex X, section 8.6.3) 


\section{Interpretations}

Concerning Annex VIII our interpretation of "close to dose levels at which toxicity to humans may be expected" is that the dose level is a LOAEL from animal studies which has been adjusted by relevant assessment factors (LOAEL/AF). The interpretation of "close to the dose levels" is that it is a dose lower than, but in the vicinity of, the dose levels at which toxicity to humans may be expected (LOAEL/AF).

Concerning Annex IX our interpretation of "high relative to dose levels at which toxicity to humans may be expected" is that the dose level is a LOAEL from animal studies which has been adjusted by relevant assessment factors (LOAEL/AF). The interpretation of "high relative to the dose levels" is that it is exposure levels higher than the dose levels at which toxicity to humans may be expected (LOAEL/AF).

Finally, concerning Annex X our interpretation of "close to dose levels at which toxicity is observed" is that the dose level is a LOAEL from animal studies. The interpretation of "close to the dose levels" is that it is a dose lower than, but in the vicinity of, the dose levels at which toxicity is observed from animal studies.

\subsection{Ecotoxicological standard information requirements}

\subsubsection{Term in column 2: "Direct and indirect exposure is unlikely"}

According to REACH several tests in the standard information requirements (column 1 of Annexes IX and X) may be omitted if "direct or indirect exposure of an environmental compartment is unlikely".

\section{General Interpretations}

"Direct exposure” is interpreted as direct emissions to a particular compartment.

"Indirect exposure" of a compartment can be caused by environmental partitioning, e.g., emissions to air can eventually (except for gases with no deposition) lead to deposition on soil and into the aquatic compartments; emissions to sewage treatment plants can end up in soil via deposition of sludge.

The interpretation of "exposure is unlikely" refers to the probability of exposure to happen, not to the degree of exposure. If the intention were to make waiving possible based on an estimate of the level of exposure then the wording would be different, e.g. "exposure is low/insignificant/-negligible" or related to possible effect concentrations. Consequently, it falls back to if there are emissions to the environment or not, if a fraction of the substance will end up in the environmental compartment in question, and how the substance is used, e.g. in closed systems. 
Below are the REACH text for the different ecotoxicogical endpoints, and the endpoint specific interpretations of the text in REACH concerning "direct and indirect exposure is unlikely".

\subsubsection{Aquatic compartment}

According to REACH bioaccumulation testing in aquatic species, preferably fish, is required in Annex IX, section 9.3.2. However, according to column 2 the study does not need to be conducted if:

"direct and indirect exposure of the aquatic compartment is unlikely”.

\section{Interpretations}

It is considered that if a substance is released into the environment, a fraction of it will end up in the aquatic compartment more or less regardless of the primary release media and the properties of the substance. This may not be applicable for substances with extreme propoerties, for instance gases with no deposition. Thus, for most substances unlikely exposure can only relate to situations where the substance is manufactured and used in systems with no emissions.

\subsubsection{Sediment}

According to REACH the sediment simulation degradation testing is required in Annex IX, section 9.2.1.4 for substances with a high adsorption to sediment. However, according to column 2 the study does not need to be conducted if:

"direct and indirect exposure of sediment is unlikely".

\section{Interpretations}

It is considered that if a substance is released into the environment, a fraction of it will end up in the aquatic compartment more or less regardless of the primary release media and the properties of the substance. If present in water, part of the substance will end up in sediment since the information requirement in this case concerns substances with a high adsorption to sediment. As for the aquatic compartment this may not be applicable for substances with extreme properties, for instance substances transformed extremely rapid by hydrolysis. Thus, unlikely exposure can only relate to situations where the substance is manufacture and used in closed systems.

\subsubsection{Soil compartment}

According to REACH the soil simulation degradation test is required in Annex IX, section 9.2.1.3 for substances with a high adsorption to soil. 
However, according to column 2 the study does not need to be conducted if:

“- direct and indirect exposure of soil is unlikely".

\section{Interpretations}

It is considered that some substances may have properties that effectively prevent partitioning to soil, thus, warranting waiving. To be able to derogate on this ground, it has to be shown that; there is no direct release to soil or air, and there is virtually no (i.e. insignificant) environmental partitioning to air or soil, and that sewage sludge contaminated with the substance is not applied to soil. If justification is based on insignificant partitioning to soil, the other prerequisites need to be fulfilled as well. However, note that soil simulation testing in according to column 1 is limited to high adsorption potential.

\subsubsection{Effects on terrestrial organisms}

\section{Annex IX}

The following tests are required in Annex IX, section 9.4:

- short-term toxicity test to invertebrates (9.4.1),

- the study on effects on soil micro-organisms (9.4.2), and

- the short-term toxicity test to plants (9.4.3)

\section{Annex $X$}

Long-term toxicity testing on soil invertebrates (section 9.4.4) and longterm toxicity testing on plants (section 9.4.6) are required.

However, according to column 2 the studies in Annexes IX and X, respectively, do not need to be conducted if:

“direct and indirect exposure of the soil compartment is unlikely".

\section{Interpretations}

Some substances may have properties that effectively prevent partitioning to soil, thus, warranting waiving. To be able to derogate, it has to be shown that; there is no direct release to soil or air, and there is virtually no (i.e., insignificant) environmental partitioning to air or soil, and that sewage sludge contaminated with the substance is not applied to soil. If justification is based on insignificant partitioning to soil, the other criteria thus need to be fulfilled as well. 


\subsubsection{Term in column 2: "Further testing"}

With minor differences depending on tonnage level and endpoint, the following text is recurrent in column 2 of REACH Annexes VIII-X:

"Further testing shall be considered/proposed if the chemical safety assessment according to Annex I indicates the need to investigate further the ... of the substance. The choice of the appropriate test(s) will depend on the results of the chemical safety assessment."

This concerns the following endpoints:

- $\quad$ Long-term aquatic toxicity (Annex VIII, 9.1.3; Annex IX; 9.1)

- Degradation (Annex VIII, IX, X; 9.2)

- Fate and behaviour (Annex X; 9.3.4)

- Long-term toxicity on terrestrial organisms (Annex X; 9.4)

- Long-term toxicity on sediment organisms (Annex X; 9.5.1) 


\section{General interpretation}

The outcome of the chemical safety assessment may influence whether a test is required or not. To our understanding the phrase "indicates the need to investigate further" implies that if further testing may e.g. reduce uncertainties and/or alter the chemical safety assessment (in any direction), this is a reason to perform that test.

However it is not completely clear to what "further" in the text relates. It could be in addition to the information required in column 1 at the same tonnage level as the text appears in column 2 and thus entail triggering of studies in addition to the standard information requirements. Alternatively, it could relate to the information required at the previous tonnage level, i.e. studies already performed, and thus entail a possibility of waiving the standard information requirement at the tonnage level in question.

Our interpretation is that "further testing" relates to the information presently available (regardless of what is already performed of the standard information required in column 1). "Further testing” should result in the information necessary to perform a chemical safety assessment indicating no need to investigate further the endpoint in question.

Hence, regarding the endpoints where the text above is used in column 2, the chemical safety assessment may give grounds for waiving a test asked for in column 1 at the tonnage level in question as well as trigger a test that may reduce uncertainties and/or alter the chemical safety assessment (in any direction). This might even be a test not specifically mentioned at any tonnage level in the standard requirements.

If the substance meets the classification criteria or not, is $\mathrm{PBT} / \mathrm{vPvB}$ or not, and/or is of concern or not, are possible outcomes of different parts of the chemical safety assessment. The actual outcome(s) of the chemical safety assessment at a certain tonnage level for a substance without a test (based on presently available data) compared with the possible outcome(s) of the chemical safety assessment based on predicted possible results (e.g. assuming extremes) of that test may in some cases be used to judge if further testing has the power to change the outcome(s), thus indicating if testing is needed or not. Evaluation of available evidence on how protective an assessment factor may be, or an analysis of uncertainties in an assessment of a specific chemical might be other ways to judge if further testing could change the outcome(s).

This means that one way to conclude if the chemical safety assessment indicates the need to further investigate at that tonnage level is to ask if the result of a test possibly could lead to a change regarding one of the following:

- classification or declassification

- $\quad$ assignment as PBT/vPvB or acquittal

- $\quad$ concern or not concern

When the answer is yes a need for further testing is indicted. If the answer is no, further testing is not warranted unless such need is indicated in some other way in the chemical safety assessment. 
Below are the REACH text for the different ecotoxicogical endpoints, with endpoint specific interpretations and implications if the text in REACH is interpreted as waiving or triggering, respectively concerning "further testing". As mentioned before waiving is defined as omission of the standard information requirements in column 1 of the corresponding Annex, while triggering is defined as further testing beyond the standard information requirements in column 1 of the corresponding Annex.

\subsubsection{Endpoint: Long-term aquatic toxicity}

Column 1 - Standard information required

According to REACH the long-term aquatic toxicity study is required in Annex IX, section 9.1. This includes: Long-term toxicity testing on invertebrates (9.1.5) and Long-term toxicity testing on fish (9.1.6).

Column 2 - Specific rules for adaptation from Column 1

\section{Annex VIII, 9.1.3}

"Long-term aquatic toxicity study as described in Annex IX shall be considered if the chemical safety assessment according to Annex I indicates the need to investigate further effects on aquatic organisms. The choice of appropriate test(s) will depend on the results of the chemical safety assessment."

\section{Annex IX, 9.1}

"Long-term toxicity testing shall be proposed by the registrant if the chemical safety assessment according to Annex I indicates the need to investigate further the effects on aquatic organisms. The choice of appropriate test(s) will depend on the results of the chemical safety assessment.”

\section{Waiving interpretations}

It is interpreted that the studies required for estimation of environmental effects in column 1 of Annex IX can be waived based on the outcome of the chemical safety assessment. For instance, if shown to be protective the shortterm studies may be used for extrapolation to long-term studies by the use of an assessment factor.

Waiving of the standard test requirements in column 1 of Annex IX implies that the information available for the chemical safety assessment will be all available information and the standard information requirements in column 1 of Annex VII (i.e. short-term toxicity testing on invertebrates, preferred species Daphnia (9.1.1) and Growth inhibition study aquatic plants, algae preferred (9.1.2)) and Annex VIII (i.e. short-term toxicity testing on fish (9.1.3) and Activated sludge respiration inhibition testing (9.1.4)). 


\title{
Triggering interpretations
}

The text in column 2 can also be interpreted as a possibility to trigger more information than the one required in column 1 at the tonnage level in question e.g. in order to demonstrate adequate control.

Justification for triggering of aquatic toxicity studies at this tonnage level will be based on all available information on exposure and effects, and in this context this implies as a minimum the standard test requirements proposed in column 1 of Annex IX (long-term toxicity testing of invertebrates and of fish).

\subsubsection{Endpoint: Degradation}

\section{Annex VIII, 9.2}

Column 1 - Standard information required

According to REACH, Annex VIII, section 9.2.2.1, a study is required on hydrolysis as a function of $\mathrm{pH}$ is required.

Column 2 - Specific rules for adaptation from Column 1

\begin{abstract}
"Further degradation testing shall be considered if the result of the chemical safety assessment according to Annex I indicates the need to investigate further the degradation of the substance. The choice of appropriate test(s) will depend on the outcome of the chemical safety assessment.”
\end{abstract}

\section{Annexes IX, 9.2}

Column 1 - Standard information required

According to REACH the following tests are required: simulation testing on ultimate degradation in surface water (9.2.1.2), soil simulation testing for substances with a high potential for adsorption to soil (9.2.1.3), sediment simulation testing for substances with a high potential for adsorption to sediment (9.2.1.4), and identification of degradation products (9.2.3).

\section{Annexes IX and $X, 9.2$}

Column 2 - Specific rules for adaptation from Column 1

\begin{abstract}
"Further biotic degradation testing shall be proposed by the registrant if the chemical safety assessment according to Annex I indicates the need to investigate further the degradation of the substance and its degradation products. The choice of appropriate test(s) will depend on the results of the chemical safety assessment and may include simulation testing in appropriate media (water, sediment or soil)."
\end{abstract}

\section{Annex X, 9.2}

Column 1 - Standard information required

No study is described beyond the information requirements in Annex IX. 


\section{Column 2 - Specific rules for adaptation from Column 1}

"Further biotic degradation testing shall be proposed if the chemical safety assessment according to Annex I indicates the need to investigate further the degradation of the substance and its degradation products. The choice of appropriate test(s) will depend on the results of the chemical safety assessment and may include simulation testing in appropriate media (water, sediment or soil)."

\section{Waiving interpretations}

It is interpreted that the studies required for estimation of degradation according to column 1 of Annex IX and/or X can be waived based on the outcome of the chemical safety assessment. For instance, if proven to be protective ready tests may be used for extrapolation to degradation half-lives in environmental compartments as recommended in the test guidance document connected to REACH.

Waiving the standard test requirements in column 1 of Annex IX implies that the chemical safety assessment will be based on the standard test requirements in column 1 of Annex VII (i.e. Ready biodegradability (9.2.1.1)) and Annex VIII (i.e. Hydrolysis as a function of $\mathrm{pH}$ (9.2.2.1)).

\section{Triggering interpretations}

The text in column 2 can also be interpreted as a possibility to trigger more information than required in column 1 at the tonnage level in question e.g. in order to demonstrate adequate control. This could for instance include tests performed under anaerobic conditions or other special conditions indicated to be needed by the chemical safety assessment.

Justification for triggering of degradation studies at these tonnage levels will be based on all available information on exposure and effects, and in these contexts this implies the standard test requirements proposed in column 1 of Annex IX.

\subsubsection{Endpoint: Fate and behaviour}

\section{Column 1 - Standard information required}

According to REACH, Annex X, 9.3.4, further information on the environmental fate and behaviour of the substance and/or degradation products is required.

Column 2 - Specific rules for adaptation from Column 1

Annex X, 9.3.4

"Further testing shall be proposed by the registrant or may be required by the Agency in accordance with Article 40 or 41 if the result of the chemical safety assessment according to Annex I indicates the need to investigate further the fate and behaviour of the substance. The choice of appropriate test(s) depends on the results of the chemical safety assessment." 


\section{Waiving interpretations}

It is interpreted that the studies required for estimation of environmental fate and behaviour in column 1 of Annex X may be waived based on the outcome of the chemical safety assessment.

Waiving of the standard test requirements in column 1 of Annex X implies that the chemical safety assessment will be based on all available information including the standard test requirements in column 1 of Annex VIII (i.e. Adsorption and desorption screening (9.3.1) and Annex IX (i.e. Bioaccumulation in aquatic species, preferably fish (9.3.2) and Further information on adsorption/desorption depending on the results of the study required in Annex VIII (9.3.3)).

\section{Triggering interpretations}

The text in column 2 can also be interpreted as a possibility to trigger more information than the one required in column 1 at the tonnage level in question e.g. in order to demonstrate adequate control.

Justification for triggering of studies on fate and behaviour at this tonnage level will be based on all available information on exposure and effects. However, it is not clearly specified what the information requirements comprises at this level.

\subsubsection{Endpoint: Long-term toxicity on terrestrial organisms}

\section{Column 1 - Standard information required}

According to REACH, Annex X, long-term toxicity testing on invertebrates (9.4.4) and long-term toxicity testing on plants (9.4.6) are required, unless already provided as part of Annex IX.

\section{Column 2 - Specific rules for adaptation from Column 1}

\section{Annex X, 9.4}

"Long-term toxicity testing shall be proposed if the result of the chemical safety assessment according to Annex I indicates the need to investigate further the effects of the substance and/or its degradation products on terrestrial organisms. The choice of appropriate test(s) depends on the outcome of the chemical safety assessment.” 


\section{Waiving interpretations}

It is interpreted that the studies required for estimation of environmental effects in column 1 of Annex X can be waived based on the outcome of the chemical safety assessment. For instance, short-term studies can, if proven to be protective be used for extrapolation to long-term studies by the use of an assessment factor.

Waiving the standard test requirements in column 1 of Annex X implies that the chemical safety assessment will be based on all the available information including the standard test requirements in column 1 of Annex IX (i.e. Shortterm toxicity to invertebrates (9.4.1), Effects on soil micro-organisms (9.4.2) and Short-term toxicity to plants (9.4.3). The choice of the appropriate test depend the chemical safety assessment.

\section{Triggering interpretations}

The text in column 2 can also be interpreted as a possibility to trigger more information than the one required in column 1 at the tonnage level in question e.g. in order to demonstrate adequate control. This could for instance include tests on non-standard organism indicated to be needed by the chemical safety assessment.

Justification for triggering of long-term toxicity studies on terrestrial organisms at this tonnage level will be based on all available information on exposure and effects, and in this context this implies the standard test requirements proposed in column 1 of Annex IX (long-term toxicity testing on invertebrates and on plants).

\subsubsection{Endpoint: Long-term toxicity on sediment organisms}

\section{Column 1 - Standard information required}

It is not clearly specified what the information requirements comprises at this level.

\section{Column 2 - Specific rules for adaptation from Column 1}

\section{Annex X, 9.5.1}

"Long-term toxicity testing shall be proposed by the registrant if the result of the chemical safety assessment according to Annex I indicates the need to investigate further the effects of the substance and/or relevant degradation products on sediment organisms. The choice of appropriate test(s) depends on the results of the chemical safety assessment.” 


\section{Waiving interpretations}

It is interpreted that the studies required for estimation of environmental effects in column 1 of Annex IX and/or X can be waived based on the outcome of the chemical safety assessment. For instance, short-term studies can, if proven to be protective be used for extrapolation to long-term studies by the use of an assessment factor.

Waiving the standard test requirements in column 1 of Annex $\mathrm{X}$ implies that the chemical safety assessment will be based on aquatic toxicity using the equilibrium partitioning method.

\section{Triggering interpretations}

Since it is not clearly specified what the information requirements comprises at this level an interpretation of triggering becomes superfluous in this context. 


\section{General rules for adaptation (Annex XI)}

\subsection{Relevant REACH text}

\subsubsection{Exposure assessment in the chemical safety assessment}

According to Article 14, “A chemical safety assessment of a substance shall include the following steps:

- human health hazard assessment;

- physicochemical hazard assessment;

- environmental hazard assessment;

- persistent, bioaccumulative and toxic (PBT) and very persistent and very bioaccumulative (vPvB) assessment.

If the substance meets the criteria for classification as dangerous in accordance with Directive 67/548/EEC or is assessed to be a PBT or vPvB, the chemical safety assessment shall include the following additional steps:

a) exposure assessment including the generation of exposure scenario(s) (or the identification of relevant use and exposure categories if appropriate) and exposure estimation;

b) risk characterisation.

"According to section 5 of Annex I "The objective of the exposure assessment shall be to make a quantitative or qualitative estimate of the dose/concentration of the substance to which humans and the environment are or may be exposed. The assessment shall consider all stages of the life-cycle of the substance resulting from the manufacture and identified use and shall cover any exposures that may relate to the hazards identified in sections 1-4.” 


\section{Interpretation}

According to this article an exposure assessment and a risk characterisation only have to be included in the chemical safety assessment if the substance meets the criteria for classification as dangerous in accordance with Directive 67/548/EEC or is assessed to be a PBT or vPvB.

This might imply that the available exposure information will only be sufficient for justification of waiving for those substances that do meet the criteria for C\&L or is assessed as PBT or vPvB. However, it is possible to provide an exposure assessment, including the generation of exposure scenario(s) (or the identification of relevant use and exposure categories if appropriate), and a risk characterisation on a voluntary basis.

Detailed knowledge on exposure is needed throughout the life-cycle, including both environmental and human exposure (occupational exposure, consumer exposure and exposure of man via the environment) of the chemical.

\subsubsection{Exposure scenario}

\section{According to Annex I, section 5,}

"Exposure scenarios are the core of the process to carry out a chemical safety assessment. The chemical safety assessment may be iterative.... with the aim to demonstrate adequate control.”

An exposure scenario is defined in article 3:37 as the set of conditions that describe how the substance is manufactured or used during its lifecycle and how manufacturer or importer controls, or recommends downstream users to control exposures of humans and the environment.

\section{Interpretation}

Concerning exposure based waiving it is important that the whole life-cycle of the chemical is considered. In case of uncertainties, e.g. with respect to potential exposure to the environment, man via the environment or consumers, waiving cannot be justified by only referring to negligible occupational exposure.

It is of importance to provide extensive information on the properties of the substance and the preparation or article of which it is incorporated, handling and use, duration of exposure, number of exposed people, frequency and concentrations, and if there is restricted handling and use.

Based on this a decision can be taken whether it is possible to waive tests, or if further testing should be proposed, on a specific tonnage level. 


\subsubsection{General rules for adaptation}

The general rules for adaptation contained in Annex XI, section 3 reads as follows:

- $\quad 3.1$ "Testing in accordance with sections 8.6. and 8.7 of Annex VIII, Annex IX and Annex X may be omitted based on the exposure scenario(s) developed in the Chemical Safety Report."

- $\quad 3.2$ "In all cases adequate justification and documentation shall be provided. The justification shall be based on an exposure assessment in accordance with section 5 of Annex I and be consistent with the criteria adopted pursuant to section 3.3, and the specific conditions of use must be communicated through the chemical supply chain in accordance with Articles 31 and 32."

- $\quad 3.3$ "The Commission shall adopt the measures designed to amend non-essential elements of this regulation by supplementing it, in accordance with the procedure referred to in Article 133(4) to set the criteria defining what constitutes adequate justification under section 3.2 by December 2008."

In addition, this general rules for adaptation is mentioned in Article 13, section 1:

"Testing in accordance with Annex VIII, sections 8.6. and 8.7, Annex IX and Annex $\mathrm{X}$ may be omitted where justified by information on exposure and implemented risk management measures as specified in Annex XI, section 3.”

\section{Interpretation}

Our general interpretation of Annex XI:3 is that waiving in this context can be risk-based since waiving should be based on the exposure scenario developed in the chemical safety assessment. The exposure is in this perspective related to a specific endpoint.

One problem with risk-based waiving that has to be solved is that the study under consideration would in itself be needed in the risk assessment in order to decide if exposure is of no concern in relation to a specific endpoint.

It is interpreted that in order to decide on waiving of a test an exposure assessment is needed. This may precede the formal exposure assessment that is part of the chemical safety assessment if the substance meets the criteria for classification as dangerous in accordance with Directive 67/548/EEC or is assessed to be a PBT or vPvB.

It remains to develop criteria for what constitutes adequate justification in the waiving proposals. According to REACH such criteria will be adopted by the Commission by December 2008. 
3.1.4 Relationship between Specific rules for adaptation (Column 2) and the General rules for adaptation (Annex XI)

Column 2 of the Annexes VII-X lists specific rules according to which the registrant may propose to omit the required standard information, replace it by other information, provide it at a later stage or adapt it in another way.

In addition to these specific rules, a registrant may propose to adapt the required standard information set out in column 1 of the Annexes according to the general rules contained in Annex XI (Annex XI:1- testing does not appear scientifically necessary, Annex XI:2 - testing is technically not possible and Annex XI:3 - substance tailored exposure driven testing).

According to Annex XI testing may be omitted based on the exposure scenario(s) developed in the Chemical Safety Report concerning sections 8.6. and 8.7 of Annex VIII, Annex IX and Annex X. This is in line with the fact that it is specifically mentioned in Annex VII that section 3 on substance-tailored exposure waiving is excepted.

If the conditions for waiving are met the registrant shall clearly state this fact and the reasons for proposing each adaptation under the appropriate headings in the registration dossier referring to the appropriate specific rules in column 2 or in Annex XI. 


\section{Interpretation}

Testing in accordance with Annex VIII (sections 8.6. and 8.7), Annex IX and Annex X may be omitted based on information on exposure according to the general rules of adaptation (Annex XI:3). In addition, testing may be omitted according to the specific rules for adaptation in Column 2 of Annexes VIII (section 8.6 and 8.7), IX and X. Omission of testing based on exposure information is not applicable below Annex VIII.

Waiving of testing according to Annex XI is based on the exposure scenario(s) developed in the Chemical Safety Report. In general testing will be performed according to column 1 of the Annexes. However, waiving might be possible for a specific exposure scenario if it can be proven that all handling and use is of adequate control, and there is no other use outside the exposure scenario.

Waiving according to Column 2 is endpoint specific and limited to the specific definitions concerning inherent properties and exposure mentioned in Column 2. In order to waive testing data the exposure has to be well known and thoroughly described, even though waiving in this context is not in itself coupled to an exposure scenario (except in the case of Annex VIII, section 8.6 and 8.7, where waiving should be "in accordance with Annex XI").

Hence, waiving according to Column 2 and Annex XI could be seen as parallel, but similar, processes and there should be no conflict between the two processes. However, REACH does not give an unambiguous guidance on the relationship between Column 2 and Annex XI and alternative interpretations have been mentioned. For instance, the specific waiving conditions in Column 2 could be seen as examples of waiving in accordance with Annex XI. Alternatively, the specific waiving conditions in Column 2 could be specifications of the general waiving conditions in Annex XI.

If testing is omitted there is uncertainty concerning the eventual effects (depending on lack of data on effects) and we consider it important to handle that uncertainty for instance by conservative estimates of theeffect considerations in question or by the use of an extra uncertainty factor.

The remaining issue in Annex XI is development of criteria what constitutes adequate justification in the waiving proposals, and the adoption of the criteria by the Commission in December 2008.

Finally, it is considered that since it is mentioned in Annexes IX and X that the registrant may propose to omit the required standard information set out in column 1 the proposal need to be reviewed. However, at this stage it is unclear if this is covered in the examination of testing proposals performed by the Agency. 



\section{Possible justification of exposure based waiving}

In order to justify waiving extensive and detailed knowledge on exposure are needed throughout the life-cycle, including both environmental and human exposure (occupational exposure, consumer exposure and exposure of man via the environment) of the chemical. One example when waiving can be adequate is if the documentation provided can prove that a substance is handled in a closed system, there is no consumers exposure and no dispersive use.

Another example where waiving of tests based on information on exposure may be appropriate is if it can be proven that a substance is totally chemically reacted during manufacturing or if the substance is permanently bound to a matrix. Under other circumstances it is not possible to reassure that exposure is negligible when there are consumer uses and/or humans can be exposed via the environment.

Under very specific circumstances exposure may also be considered as negligible in a specialised industrial situation with a small, welldefined and trained group of people using appropriate risk management measures to prevent exposure.

In this context it has to be highlighted that Personal Protective Equipment (PPE) is a last resort risk reduction activity used when other strategies are not available or effective. PPE does not remove the problem of exposure, and the actual protection from the use of PPE is often uncertain. According to Directive: 89/656/EEC Use by Workers of Personal Protective Equipment at the Work Place, Article 3, "Personal protective equipment shall be used when the risks cannot be avoided or sufficiently limited by technical means of collective protection or by measures, methods or procedures of work organisation”.

In some cases it may not be necessary to generate missing information because risk management measures and operational conditions which are necessary to control a well-characterised risk may also be sufficient to control other risks, which will not therefore need to be characterised precisely (Annex I, section 0.5, in accordance with section 3 of Annex XI). 



\section{Issues for further discussion}

- Waiving in REACH, Annex XI and column 2 of Annexes VIII-X, is considered to be risk-based, i.e. relies on both exposure and hazard.

- One main problem with risk-based waiving that has to be solved is that the effect-study under consideration would in itself be needed in the risk assessment in order to decide if exposure is negligible in relation to the specific endpoint.

- Further, it is interpreted that in order to decide on waiving of a test an exposure assessment is needed. This precedes the formal exposure assessment that is part of the chemical safety assessment if the substance meets the criteria for classification as dangerous in accordance with Directive 67/548/EEC or is assessed to be a PBT or vPvB.

- How to determine an acceptable risk.

- One way of doing this might be the use of TTC. In this case the choice of TTC-value is critical. The TTC has to be low enough to ensure sufficient level of protection in case there is no substance specific information.

- An alternative way of solving this might be the use of an additional uncertainty factor if the test is waived based on exposure information. The critical issue in this case is the magnitude of the factor since it has to be high enough to ensure sufficient level of protection.

- $\quad$ REACH does not give an unambiguous guidance on the relationship between Column 2 and Annex XI and this need to be further discussed. Alternative interpretations have been mentioned. For instance waiving according to Column 2 and Annex XI could be seen as parallel, but similar, processes and there should be no conflict between the two processes. In addition, the specific waiving conditions in Column 2 could be seen as examples of waiving in accordance with Annex $\mathrm{XI}$, or as specifications of the general waiving conditions in Annex XI. In each case, the exposure has to be well known and thoroughly described in order to decide whether waiving is applicable or not.

- If testing is omitted there is uncertainty concerning the eventual effects (depending on lack of data on effects) and it is considered important to handle that uncertainty for instance by conservative estimates of the effect considerations in question or by the use of an extra uncertainty factor.

- Since the registrant may propose to omit the required standard information set out in column 1, this proposal need to be reviewed. However, at this stage it is unclear whether it should be covered in the exa- 
mination of the testing proposal performed by the Agency. Review of the waiving proposals may be one way forward in developing adequate criteria defining what constitutes adequate justification for risk-based waiving that has to be done by December 2008 . 


\section{Sammenfatning}

Detta dokument har tagits fram för att skapa diskussion kring, och vägledning för, när det är möjligt att avvika från de tester som normalt krävs i REACH baserat på information om exponering.

Arbetet, som har sammanställts åt Nordiska Kemikaliegruppen inom Nordiska Ministerrådet, har utförts av en konsult inom ramen för ett det Nordiska Projektet rörande InformationsStrategier (NOIS) och har vägletts av en Nordisk styrgrupp. Dokumentet utgör dock inte de Nordiska ländernas officiella ståndpunkt.

Syftet med arbetet var att tolka och diskutera kring:

- de specifika reglerna när det gäller undantag för testning enligt kolumn 2 i Bilagorna VIII-X i REACH

- de generella reglerna när det gäller undantag för testning i Bilaga XI i REACH

- när ytterligare tester kan föreslås enligt kolumn 2 i Bilagorna VIII-X i REACH

Enligt REACH ska exponeringsscenarier som utvecklats i kemikaliesäkerhetsbedömningen visa att man har tillräcklig kontroll på eventuella risker. Baserat på detta kan beslut tas om det är möjligt att frångå testning (waiving), eller om ytterligare tester skall föreslås (triggering), vid de angivna tonnagenivåerna. Att frångå testning definieras i detta sammanhang som att man avviker från den information som normalt krävs vid den aktuella tonnagenivån, medan utlösande av testning definieras som ytterligare tester bortom den information som normalt krävs vid den aktuella tonnagenivån.

Toxikologiska tester kan även anpassas genom att välja exponeringsväg beroende på hur människor exponeras. Detta kommer dock inte diskuteras ytterligare i detta dokument.

En tolkning av REACH som gjorts i detta arbete är att undantag för testning enligt REACH kan anses vara riskbaserat, det vill säga beror på både exponering och ämnets inneboende egenskaper snarare än enbart på exponeringen. För att kunna rättfärdiga att man frångår testkraven för ett ämne i REACH är det nödvändigt med omfattande och detaljerad kunskap om exponering over hela livscykeln, både när det gäller hälsa och miljö.

Det finns problem med riskbaserade undantag för testning som måste lösas. I vissa fall behöver man till exempel effektstudien som man vill göra undantag för som underlag för att kunna avgöra om exponeringen är försumbar, vilket innebär att det blir ett cirkelresonemang. Ett annat pro- 
blem är att man behöver göra en exponeringsbedömning och ta fram ett exponeringsscenario för att kunna göra undantag för testning. Detta krävs formellt först då ämnet uppfyller klassificeringskriterierna eller bedöms vara PBT eller vPvB.

En sak som diskuteras i dokumentet är hur man fastställer en acceptabel risk. Ett sätt som har föreslagits är använda sig av TTC (Threshold of Toxicological Concern). Valet av TTC-värde blir då kritiskt eftersom TTC måste vara tillräckligt lågt för att försäkra sig om en tillräcklig skyddsnivå. Ett annat alternativ skulle kunna vara att använda ytterligare osäkerhetsfaktorer om informationskraven frångås. Problemet här blir att fastställa storleken på denna extra faktor som måste vara tillräckligt stor för att försäkra sig om en tillräcklig skyddsnivå.

Ett exempel där undantag för testning skulle kunna vara möjlig är om det kan visas att ämnet enbart hanteras i ett slutet system och att ingen konsumentexponering eller spridd användning förekommer. Ett annat exempel är om det kan visas att ämnet är fullständigt bundet till matrisen. Under andra omständigheter är det inte möjligt att försäkra sig om att exponeringen är försumbar om det förekommer konsumentanvändning och/eller om människor kan exponeras via miljön. Exponering kan även anses vara försumbar då en liten väldefinierad och vältränad grupp som använder lämplig skyddsutrustning för att förhindra exponering exponeras. I detta sammanhang bör det nämnas att personlig skyddsutrustning (PPE) ska ses som en sista utväg för att förhindra exponering.

Förhållandet mellan de specifika kraven för att frångå testning enligt kolumn 2 i Bilagorna VIII-X och de generella kraven för att frångå testning enligt Bilaga XI är oklara i REACH och behöver diskuteras vidare. I båda fallen måste man ha stor kunskap om exponeringen och beskriva den ordentligt för att kunna bedöma om det är lämpligt att frångå informationskraven i REACH.

Eftersom registranten enligt REACH kan föreslå att informationskraven ska frångås bör ett sådant förslag granskas. För närvarande är det dock oklart om denna del kommer att granskas och i så fall av vem. Granskning av förslag till undantag skulle dock kunna vara ett sätt att utveckla kriterier för vad som utgör tillräcklig motivering för att frångå informationskraven. 